\title{
A BUSY COPYIST AND A SHY COMPOSER TWO SIDES OF FRANCESCO BARSANTI (ca. 1690-1775)
}

\author{
MICHAEL TALBOT \\ University of Liverpool
}

Izvleček: Francesco Barsanti, italijanski glasbeni imigrant $v$ Britaniji, je za dodatni zaslužek ob igranju v orkestru in učenju delal tudi kot glasbeni kopist. Medtem ko je bila njegova inštrumentalna glasba natisnjena, so njegova vokalna dela večinoma ostala razpršena $v$ rokopisih, pogosto brez navedbe avtorja, med deli drugih skladateljev, katerih dela je prepisoval.

Ključne besede: Francesco Barsanti, glasbeni kopist, glasba v Britaniji, vokalna glasba.

\begin{abstract}
Francesco Barsanti, an Italian immigrant musician in Britain, worked as a copyist to supplement his income from orchestral playing and teaching. Whereas his instrumental music was published, his vocal music survives almost entirely in manuscript, being interspersed, often anonymously, among music by other composers that he himself copied.
\end{abstract}

Keywords: Francesco Barsanti, music copying, music in Britain, vocal music.

\section{Music Copyists in Eighteenth-Century Britain}

The historian John Rosselli once gave the title "A Profession of Sorts" to a chapter on the position of the impresario in nineteenth-century Italian opera, opening with the sentence: "Almost anyone could become an operatic impresario."1 Much the same could be said of the profession of music copyist between the seventeenth and nineteenth centuries. The minimum requirements were very basic. One needed to be musically literate, to have fluent and legible (if not necessarily calligraphic) handwriting and also to be prepared to work intensively for short periods in order to complete jobs on time. Sometimes, there were added requirements, such as conformity to the "house style" of a copying shop or scriptorium - this could be particularly relevant in cases where a single, large task such as the copying of an opera was parcelled out among many hands - or the adaptation of an existing part to create a new part, such as occurred when oboe parts were formed extempore from ripieno violin parts. ${ }^{2}$ Above all, copyists needed at all times to be intelligent,

I am very grateful to Jasmin Cameron for reading, and commenting on, an early draft of this article.

1 Rosselli, Opera Industry in Italy, 17.

2 This particular case is discussed in Rousseau, "Copiste," 271. Active as a music copyist in his 
attentive and accurate: qualities that we often find wanting when we examine their handiwork today, and the absence of which was lambasted with almost satirical vehemence in an article of 1749 by Friedrich Wilhelm Marpurg. ${ }^{3}$

In Italy, where, as Charles Burney remarked in 1771, the music copyist's trade seemed "more brisk and profitable than any other" on account of the virtual absence of music engraving and the huge demand for new music on the part of Italians and visitors alike, ${ }^{4}$ music copying, often undertaken in specially appointed premises (copisterie), was potentially a full-time profession. Indeed, a particularly expert copyist could sometimes achieve celebrity status. ${ }^{5}$ In Britain, ${ }^{6}$ by contrast, the ready availability, for the most popular genres, of cheaper engraved music obtainable from music shops rendered copying more of a "niche" occupation suited to part-time work. However, such niches were numerous. Most music, sacred or secular, for more than one voice circulated only in manuscript, exactly as in Italy. The same was obviously true of any music fresh from the composer's pen and awaiting publication. Because of the large amateur participation in music-making, there was a market for customized albums: anthologies of music compiled for one user, often with an instructional purpose. There was also a large community of music collectors distinct from (though inevitably overlapping with) both music patrons and professional musicians. Many of these musicians, out of personal interest or in order to enlarge their repertoire, made copies for private use. The cult of "ancient" music, which grew in strength as the eighteenth century progressed, encouraged the copying of little-known music from the past, both manuscript and printed. Finally, there was in Britain an important role for what one might call the "transcriber-cum-arranger:" a copyist who deliberately altered the text transmitted by the exemplar. This alteration could take the form of simplification, as when operatic arias were presented with the loss of the less essential instrumental components (for example, second violin or viola parts) in order to make the music accessible

youth, Rousseau wrote a highly personal and surprisingly detailed entry for his old profession in his Dictionnaire de musique. While adamant that a copyist should not seek to "improve on" the composer's musical intentions (ibid., 267-268), Rousseau was very keen that he should correct obvious slips and rectify inconsistencies in the manner of an editor.

3 Marpurg, untitled article. The errors and blemishes listed (p. 312) include the writing of sharps in place of flats, the misreading of bass figures, wrong notes, missing or superfluous bars, text crossed or scratched out, pasted-over slips, bad vertical alignment, incorrect note-values, inexactly calculated rests, incorrect clefs, misaligned textual underlay, separate flags in place of required beaming, trills in place of appoggiaturas and missing dots. Marpurg's disparagement of the quality of the musical copies circulating in Germany formed part of his argument in favour of the expansion of music engraving there.

4 Burney, Present State of Music in France and Italy, 190.

5 For instance, Vivaldi's nephew Pietro Mauro, a former operatic tenor and leader of his own troupe, abandoned his not very successful life on the road and settled down in Venice to become a music copyist. The diarist Pietro Gradenigo noted in 1760 that Mauro was the city's best music copyist and even corresponded with the king of Sweden. See White and Talbot, "Pietro Mauro, detto 'Il Vivaldi'," 54-55.

6 By "Britain" I mean in all instances "Britain with Ireland:" until the Act of Union passed in 1800 Ireland was a distinct political entity with its own parliament, albeit under the same crown. 
to small amateur ensembles. ${ }^{7}$ It could equally well take the form of elaboration, as when solo sonatas were converted into trios, or when four-part textures were expanded to seven parts through the provision of concertino-ripieno contrast; this type of alteration served the needs of the music societies that were springing up everywhere in Britain. ${ }^{8}$ Not even France equalled Britain in its liking for such altered versions. And just as simple copies were apt to shade into arrangements, the latter, too, sometimes developed yet further into radical revisions, even ones containing a substantial amount of new composition. ${ }^{9}$

Since music copying was in eighteenth-century Britain largely an anonymous activity (except among certain collector-copyists), identification of individuals is difficult. The most common route to identification is when the copyist was also a composer for whom an autograph manuscript, and therefore a proven specimen of his scribal hand, is available. At present, the knowledge we possess is very piecemeal. The Image Gallery hosted by the website of the pre-1850 manuscripts database of RISM (UK) ${ }^{10}$ has made a good start, but only scratches the surface: what is now needed in order for further progress to be made is a large-scale, preferably not time-limited, collaborative project.

As we saw, music-copying in Britain was predominantly a part-time occupation undertaken alone or in an informal and usually impermanent group. In London, where orchestral musicians were most numerous, there were large numbers of rank-and-file instrumentalists whose income from playing was too small to support them in comfort, but who at least had time on their hands, not needing to practise overmuch, go touring as soloists or constantly attend the nobility. ${ }^{11}$ They formed an important category among music copyists, and my impression is that they predominated, perhaps in almost monopolistic fashion, among the collectives responsible for preparing copies for the opera houses and other institutions or societies employing orchestras. ${ }^{12}$ Viola players appear to have formed an important contingent among these player-copyists. They included Johann Georg Linike, John Christopher Smith the Elder, Thomas Rawlings, ${ }^{13}$ Anthony Werner and Francesco Barsanti, the subject of this article.

7 A score of this kind is equivalent to the partition réduite favoured in France for similar purposes.

8 See Halton and Talbot, "Choice Things of Value," 12-13.

9 A good case in point is the collection entitled Twelve Concertos in Seven Parts [...] Composed by Sig. ${ }^{r}$ Domenico Scarlatti (London: Author, 1743), which was arranged, but also partly composed, by Charles Avison.

${ }^{10}$ See http://picasaweb.google.com/musicmss.

${ }^{11}$ In Landgraf and Vickers, Cambridge Handel Encyclopedia, 164, we find the statement: "The major copyists were underemployed musical performers."

12 The team of collaborating copyists called by Handel scholars the "Smith Scriptorium" (after its senior figure, John Christopher Smith) or "Handel-Smith Scriptorium" is a prominent example.

${ }^{13}$ The activity as copyist of Thomas Rawlings (or Rawlins), Barsanti's orchestral colleague and the father of the latter's best-known pupil, Robert Rawlings, is discussed in Graydon Beeks, Making a Living in the Pit. 


\section{Introducing Francesco Barsanti}

The life and career of Barsanti, traced in a recent article of which I was a co-author, have recently become somewhat clearer. ${ }^{14}$ After Francesco Geminiani, he was certainly the most interesting, and arguably also the most important, Italian immigrant musician continuously active in Britain in the central decades of the eighteenth century. To summarize: born in Lucca in 1690 or shortly afterwards, Barsanti abandoned university studies in Padua to become a musician. Briefly active as an oboist (and player of other treble woodwind instruments) in Bologna and Massa, he came to England around 1723 (not in 1714 as assumed by Hawkins and many later writers). ${ }^{15}$ There, he carved out a living as a "jobbing" oboe player, teacher, composer and arranger. Composition was his major interest. Between 1724 and 1769 he produced and published seven collections of mainly instrumental music (six bearing an opus number), each of which is different in nature, and most of which include attractive experimental features. ${ }^{16} \mathrm{He}$ brought with him from Italy an interest in music theory; like his friend (and fellow Lucchese) Geminiani, he gravitated towards the conservative wing of British musical life, participating in and contributing to the growing vogue for "ancient" music (a loose term embracing not only music of the Renaissance but also stile antico compositions from after 1600 and, indeed, any music, however recent, with a solid contrapuntal basis) and also for "national" music (of Scotland, Ireland etc.). ${ }^{17}$ He spent most of his time in London, but around 1731 worked for a while in York and the North-East, where he acquired useful patrons. Between 1735 and 1743 he was in the full-time service of the Musical Society of Edinburgh. He returned to London, but at some point between then and ca. 1750 apparently visited, perhaps only briefly, the Northern Netherlands. After his return from Scotland, he appears to have been active as a player of the viola rather than the oboe. In later life he was a member of the Madrigal Society, which he joined in 1759, and there is evidence from the copying work he undertook that he was associated with the Academy of Ancient Music (hereafter, AAM), although his actual membership of the Academy has not been confirmed.

Contemporary testimony portrays Barsanti as a rather timid person, who shunned the limelight and avoided controversy. ${ }^{18}$ Whereas composers who were also performers good enough to lead concerts and/or feature there as soloists could use their public appearances

${ }^{14}$ Cameron and Talbot, "Many-Sided Musician.” I am indebted to Jasmin Cameron also for many materials and ideas used for the present article.

${ }^{15}$ Sir John Hawkins, General History of the Science and Practice of Music, 5:372.

${ }^{16}$ Ignoring Barsanti's published arrangements of music by others, these collections were, in chronological order: Sonate a flauto [...] con basso, op. 1 (London, 1724); VI Sonate per la traversiera [...] con basso, op. 2 (London, 1728); A Collection of Old Scots Tunes (Edinburgh, 1742); Concerti grossi, op. 3 (Edinburgh, 1742); Nove overture a quattro, op. 4 (London, ca. 1750); Sei antifone, op. 5 (London, ca. 1760); Six Sonatas for Two Violins and a Bass, op. 6 (London, 1769).

${ }^{17}$ The sense in which, for Barsanti, "national" music became a kind of "ancient music by other means" is explored in Talbot, "Francesco Barsanti and the Lure of National Song."

${ }^{18}$ The main sources for this description are Baretti, Voice of Discord, 32, 34 and 36; and Hawkins, Anecdotes, Biographical Sketches and Memoirs, 1:215. 
as a springboard for publishing and disseminating their works and building their reputation, this well-trodden route was closed to him. Instead, he had to secure the support of patrons willing to subsidize his publications, in which he had some success. However, several of his compositions, particularly vocal ones, remained outside the neatly packaged sets and needed dissemination via some other means. Barsanti found an unorthodox solution: he inserted these compositions, generally in ones and twos, in the copies he made of music by other composers. These insertions were always discreet and sometimes almost clandestine, in the sense that he often omitted his name or, in one known instance, represented it by a monogram (composed of the letters "FMB," standing for "Francesco Maria Barsanti"). In this way he satisfied his urge as a composer in an unassertive manner in keeping with his character. Those who received the copies evidently tolerated, and perhaps even welcomed, the additions: none of the pieces by Barsanti seems to have provoked an owner into making a comment, still less a deletion. On the other hand, no evidence has emerged to suggest that Barsanti was ever required or even encouraged to contribute music of his own to the collections he was commissioned by others to copy.

\section{Barsanti as Copyist}

The first inkling that Barsanti's hand might be identifiable arose when it became evident that the great majority of his surviving works in manuscript (almost entirely vocal compositions - for some reason, hardly any of his instrumental music has come down in manuscript form), though widely dispersed, were in the same hand. ${ }^{19}$ Moreover, certain pieces bore signs of compositional correction, suggesting that author and scribe were the same person. Irrefutable confirmation that he was indeed Barsanti arrived when the handwriting of the textual underlay of the copies in question was compared with that of surviving written documents (a letter and a receipt) of the composer. ${ }^{20}$ Quite by chance, the same hand appeared in various manuscripts associated with the AAM that were being studied around the same time by another scholar in preparation for an article aiming to reconstruct as far as possible the contents of the famous library of that institution and to give information on the present-day location of its surviving items. ${ }^{21}$ Through the pooling of information, I was able quickly to expand my list of music copied by Barsanti and extend

19 The one significant exception in the instrumental domain is a manuscript containing the six Op. 1 sonatas in Parma, Biblioteca Palatina, Sanvitale Sanv.D.2, which still awaits evaluation. The vocal compositions by Barsanti copied by other hands comprise: parts for two Op. 5 motets and a madrigal in the library of the Madrigal Society (GB-Lms) on deposit since 1954 at the British Library (shelfmark Mad. Soc. A 6-11); scores of the same two motets and madrigal made in 1806, probably from the GB-Lms parts, by the tenor and collector William Clarke (1737/8-1820), in the library of the Royal Academy of Music (GB-Lam, MSS 158 and 163); a catch dated 1763 in the collection of the Noblemen and Gentlemen's Catch Club on deposit at the British Library since 1952 (H.2788.p (109)).

${ }^{20}$ The receipt is reproduced in facsimile in Cameron and Talbot, "Many-Sided Musician," 125.

${ }^{21}$ Johnstone, "Westminster Abbey and the Academy of Ancient Music." I am exceedingly grateful to the author for letting me have sight of early drafts of his article and, in particular, for bringing 
it to cover collections in which no work by him appeared. A brief published account of Barsanti's activity as a copyist appeared shortly afterwards, ${ }^{22}$ and this led in turn to a private communication through which a rather interesting addition to the list was made. ${ }^{23}$

Table 1 lists the twenty-one musical sources comprising or containing works copied by Barsanti that are currently known. The order in which they are presented is not chronological, but has been chosen to facilitate their discussion. Comments on each item follow.

Table 1 A list of manuscript sources containing music wholly or partly in Barsanti's hand

\begin{tabular}{|c|c|c|c|c|c|}
\hline Item & Library & Shelfmark & Brief Description of Content & $\begin{array}{l}\text { Works by } \\
\text { Barsanti } \\
\text { Contained }\end{array}$ & $\begin{array}{l}\text { Date } \\
\text { (est.) }\end{array}$ \\
\hline 1 & D-Hs & $\mathrm{M} \mathrm{A} / 833$ & $\begin{array}{l}135 \text { Italian cantatas for voice and b.c. by } \\
\text { numerous named composers }\end{array}$ & 5 cantatas & $1733-35$ \\
\hline 2 & GB-Lam & MS 132 & $\begin{array}{l}29 \text { Italian cantatas for voice and b.c. by } \\
\text { numerous named composers }\end{array}$ & 3 cantatas & $1745-75$ \\
\hline 3.1 & I-Rama & A. Ms. 3702 & $\begin{array}{l}\text { Operatic excerpts and cantatas by numerous } \\
\text { composers, mostly named }\end{array}$ & 1 cantata & $1733-34$ \\
\hline 3.2 & I-Rama & A. Ms. 4771 & $\begin{array}{l}4 \text { cantatas and } 1 \text { aria by various composers, } \\
\text { partly named }\end{array}$ & - & $1733-34$ \\
\hline 4 & GB-Lbl & Add. MS 5322 & 12 chamber duets by Handel & - & $1745-75$ \\
\hline 5 & GB-Lbl & Add. MS 5329 & $\begin{array}{l}26 \text { chamber duets, mostly for soprano and } \\
\text { b.c., by Steffani }\end{array}$ & - & $1745-75$ \\
\hline 6 & GB-Lbl & Add. MS 5330 & $\begin{array}{l}30 \text { chamber duets for soprano and alto by } \\
\text { Steffani }\end{array}$ & - & $1745-75$ \\
\hline 7 & GB-Lbl & Add. MS 5331 & $\begin{array}{l}20 \text { chamber duets, mostly for soprano and } \\
\text { tenor, by Steffani }\end{array}$ & - & $1745-75$ \\
\hline 8 & GB-Lbl & Add. MS 5332 & 21 chamber duets for 2 sopranos by Steffani & - & $1745-75$ \\
\hline 9 & GB-Lbl & Add. MS 5335 & $\begin{array}{l}19 \text { chamber duets by } 6 \text { different Italian } \\
\text { composers }\end{array}$ & - & $1745-75$ \\
\hline 10 & GB-Bu & $\begin{array}{l}\text { Barber MS } \\
5005\end{array}$ & $\begin{array}{l}20 \text { chamber duets by Steffani, mostly } \\
\text { coincident with those in GB-Lbl, Add. MS } \\
5331\end{array}$ & - & $1745-75$ \\
\hline 11 & $\begin{array}{l}\mathrm{CH}- \\
\text { CObodmer }\end{array}$ & Ms. 11461-7 & $\begin{array}{l}\text { Pieces for solo keyboard, voice and keyboard } \\
\text { and treble instrument and keyboard }\end{array}$ & 6 French airs & 1743 \\
\hline 12 & GB-Lbl & RM 24.c.16 & $\begin{array}{l}13 \text { Italian and English madrigals, mostly } \\
\text { in } 5 \text { parts }\end{array}$ & - & $1745-75$ \\
\hline 13 & GB-Lbl & RM 22.m.2 & $\begin{array}{l}12 \text { sacred vocal compositions in } 5 \text { parts by } \\
\text { Palestrina }\end{array}$ & - & $1745-75$ \\
\hline 14.1 & GB-Lbl & $\begin{array}{l}\text { RM 24.d.15 } \\
(1 .)\end{array}$ & $\begin{array}{l}10 \text { motets by Victoria, } 11 \text { motets by } \\
\text { Palestrina, all in } 4 \text { parts }\end{array}$ & - & $1745-75$ \\
\hline
\end{tabular}

to my attention the appearance of the same copyist's hand in the sources identified below as items $4-10,12-14$ and $16-21$.

22 Talbot, "Unexpected Handel Copyist."

${ }^{23}$ My informant was Donald Burrows, to whom I am very grateful for letting me see a reproduction of the manuscript and for providing helpful comments on the resulting article (see later, n. 40). 


\begin{tabular}{|c|c|c|c|c|c|}
\hline Item & Library & Shelfmark & Brief Description of Content & $\begin{array}{l}\text { Works by } \\
\text { Barsanti } \\
\text { Contained }\end{array}$ & $\begin{array}{l}\text { Date } \\
\text { (est.) }\end{array}$ \\
\hline 14.2 & GB-Lbl & $\begin{array}{l}\text { RM 24.d.15 } \\
\text { (2.) }\end{array}$ & $\begin{array}{l}1 \text { motet by Richafort, misattributed to } \\
\text { "Adrianus" [Willaert or Coclico] }\end{array}$ & - & $1745-75$ \\
\hline 15 & GB-Lcm & MS 208 & $\begin{array}{l}\text { Gesualdo's first and second books of } \\
\text { madrigals }\end{array}$ & 1 catch & $1745-75$ \\
\hline 16 & GB-Lcm & MS 483 & $\begin{array}{l}\text { Pergolesi's Stabat Mater and Salve } \\
\text { Regina in C minor, transposed to A minor }\end{array}$ & - & $1745-75$ \\
\hline 17 & GB-Lcm & MS 1029 & $\begin{array}{l}\text { Terradellas's motet Luminosa consurgit } \\
\text { (3 separate vocal parts) }\end{array}$ & - & $1745-75$ \\
\hline 18 & GB-Lcm & MS 1074 & Miscellaneous sacred works & 2 motets & $1745-75$ \\
\hline 19 & GB-Lwa & CG 26 & $\begin{array}{l}\text { Pergolesi's (?) Miserere in C minor } \\
\text { (Paymer 71) }\end{array}$ & - & $1745-75$ \\
\hline 20.1 & GB-Lwa & CG 59 & $\begin{array}{l}\text { 61 4-part madrigals, motets etc. in score by } \\
\text { numerous composers, mostly named }\end{array}$ & $\begin{array}{l}1 \text { Latin motet, } 1 \\
\text { Hebrew sacred song }\end{array}$ & $1745-75$ \\
\hline 20.2 & GB-Lbl & Add. MS 31442 & 4 partbooks matching item 20.1 & As item 20.1 & $1745-75$ \\
\hline 21 & GB-Lwa & $\mathrm{CJ} \mathrm{lb}$ & $\begin{array}{l}\text { Individual vocal and contrabass parts for } 3 \\
\text { motets in Barsanti's Op. } 5\end{array}$ & As previous column & 1760 \\
\hline
\end{tabular}

\section{Item 1}

This is a two-volume collection containing a total of 135 Italian-language cantatas for voice (generally soprano) and basso continuo purchased at an unknown time and place by the nineteenth-century Handel scholar Friedrich Chrysander and since 1875 held by what is today the Staats- und Universitätsbibliothek Hamburg "Carl von Ossietzsky" (D-Hs). ${ }^{24}$ The sole scribe, Barsanti, appears to have prepared it for his personal use as a central stock of cantatas from which copies could be prepared for any purpose. The paper is used economically: many cantatas straddle gatherings or begin on verso sides. From this one may infer that the pieces were entered consecutively, so that that their sequence reflects exactly the chronology of copying, the second volume carrying on from the first.

The approximate date of the manuscript is ascertainable both from the single type of paper used ("C 30 " in the Burrows-Ronish catalogue, ${ }^{25}$ with the date-range 1728-1739) and from the content. In descending order of the number of cantatas contributed, the composers represented are shown in the following tabulation:

\begin{tabular}{|l|c|l|}
\hline Composer & Total & Position within the Collection \\
\hline Astorga, Emanuele d' & $(42)$ & $1-6,10,28-30,32-33,37,49-52,55-58,71-74,76-77,92-106$ \\
\hline Marcello, Benedetto & $(21)$ & $7-9,34-36,46-48,79,114-124$ \\
\hline Scarlatti, Alessandro & $(14)$ & $40-41,61-62,81-90$ \\
\hline Gasparini, Francesco & $(11)$ & $31,39,42-45,63-64,67-68,109$ \\
\hline
\end{tabular}

${ }^{24}$ Musiksammlung, M A/833 (Bde I-II). Items 1-66 occupy the first volume (pp. 1-417), items 67-135 the second (pp. 1-402). Details of the contents and their pagination are obtainable via https://opac.rism.info.

${ }^{25}$ Burrows and Ronish, Catalogue of Handel's Musical Autographs. 


\begin{tabular}{|l|c|l|}
\hline Composer & Total & Position within the Collection \\
\hline Handel, George Frideric & $(11)$ & $19-27,110-111$ \\
\hline Porpora, Nicola & $(10)$ & $54,59,65,125-131$ \\
\hline Barsanti, Francesco & $(5)$ & $17-18,60,69-70^{*}$ \\
\hline Bononcini, Giovanni & $(3)$ & $12-13,108$ \\
\hline Mancini, Francesco & $(3)$ & $15,112-113$ \\
\hline Pescetti, Giovanni Battista & $(3)$ & $132-133,135$ \\
\hline Sammartini, Giuseppe & $(2)$ & 38,75 \\
\hline Sandoni, Pietro Giuseppe & $(2)$ & 16,78 \\
\hline Arresti, Giulio Cesare & $(1)$ & 91 \\
\hline Bencini, Pietro Paolo & $(1)$ & 107 \\
\hline Corradini, Francesco & $(1)$ & 66 \\
\hline Hasse, Johann Adolf & $(1)$ & 80 \\
\hline Leporati, Domenico & $(1)$ & 11 \\
\hline Porsile, Giuseppe & $(1)$ & 14 \\
\hline Sarro, Domenico & $(1)$ & 53 \\
\hline Zipoli, Domenico & $(1)$ & 134 \\
\hline Grand total & $(135)$ & $1-135$ \\
\hline
\end{tabular}

* The five cantatas by Barsanti are: Oh giorno, oh infausto giorno (17); Un sospiro, ah che si muore (18); Chi mai vife' si belle (60); Equal legge m' imponi (69); Oh quante volte, oh quante (70). The large number of minor modifications made to these cantatas after their initial entry into the volume suggests that their composer made practical use of them over a long period of time.

The first five names in the list, with Astorga massively dominant, are all "classic" late-Baroque cantata composers whom one expects to encounter in an anthology prepared in England. The remainder are a mixture of very minor composers, whose familiarity to Barsanti may in some cases go back to his formative years in Italy, and rising stars of the Italian operatic scene, many in the ambit of the Opera of the Nobility from 1733 onwards. It is significant that the collection ends (discounting a single cantata by Zipoli) with cantatas by Porpora and Pescetti, who both visited London in that connection. ${ }^{26}$ At all events, the final works must predate June 1735, when Barsanti moved to Edinburgh and no longer had easy access to the repertory of this milieu. The cantatas heading the first volume do not appear to have been entered many years previously, so a time-frame of 1732-1735 (bearing in mind his absence from London in 1731) can tentatively be proposed. How and where he gained access to the copy texts is unknown, but it seems likely that through personal connections he was permitted to copy items from major repositories such as the libraries of the AAM and of Handel, and quite possibly the royal collections.

Barsanti's access to a largish group of cantatas by Handel is noteworthy (that he moved in Handel's orbit is also suggested by item 11 in Table 1). One interesting detail would suffice to indicate his role as scribe even in the absence of other pointers: whereas all other composers named at the head of a cantata are dignified with the appropriate title

${ }^{26}$ The first known report of Pescetti's presence in England dates from 1736, but since no new operas by him were produced in Italy between 1732 and 1747 he may well have arrived in London one or two years earlier. 
("Signor" or its equivalent), the copyist modestly (or is it ostentatiously?) omits a title for Barsanti on each of the five occasions when his name appears. ${ }^{27}$

\section{Item 2}

How item 1 was used in practice is shown beautifully by this collection of 29 continuo cantatas preserved in the library of the Royal Academy of Music, London (GB-Lam). ${ }^{28}$ It is an anthology made up of pieces from the Hamburg manuscript that is more or less representative of the latter's content (except for the absence of Handel). Barsanti may well have had a free hand in choosing and ordering the items. The fact that nos. 9-13 in the London manuscript are the same five Astorga cantatas, identically ordered, as nos. 92-96, in the Hamburg manuscript shows that he did not need to agonize over his selection. He took care to include three of his own cantatas in the anthology. ${ }^{29}$

The volume was very likely prepared, either on commission or as a gift, for its first known owner, the singer, organist, composer and keen music collector William Savage (1720-1789), who as a member of the Madrigal Society and enthusiast for "ancient" music moved in the same circles as Barsanti. After the death, in 1816, of Savage's clergyman son Edward, who had inherited his music, the latter's widow sold the collection privately to the singer and collector Richard John Samuel Stevens (1757-1837), a former pupil of William Savage. Stevens's music was put up for auction in 1872, when it was acquired by the Royal Academy of Music.

\section{Items 3.1 and 3.2}

The library (today termed the Bibliomediateca) of the Accademia Nazionale di S. Cecilia, Rome (I-Rama), acquired in 1926 the Fondo Mario, which is the former collection of the eminent singer Giovanni Matteo De Candia (who adopted the surname "Mario"). Mario (1810-1883) amassed a considerable library of music during his travels. ${ }^{30}$ It was almost certainly in London that he acquired the collection of cantatas (mostly continuo cantatas for soprano) that in their present-day bindings are distributed between several volumes, some of which also contain unrelated vocal material. Most of the cantatas are housed in the volume A Ms. 3710 and its continuation A Ms. 3702, but a few extra items (including some that at an earlier stage became accidentally detached from the main volumes) occur in A Mss. 2619, 2724, 3704, 3705, 3710 and 4771.

These cantatas were copied, presumably also in London, by a scriptorium of at least six copyists plus (peripherally) Barsanti. It seems probable, given the strong connections between the milieux of the Italian opera and cantata (which involved the same singers), that this collective was ordinarily concerned with providing performance material for

${ }^{27}$ The Hamburg volumes contain all the surviving cantatas by Barsanti currently known, which suggests that at the time of compilation they were the only ones he had written.

${ }^{28}$ MS 132. The manuscript has 199 numbered pages with music, and Barsanti has added a contents list at the front.

${ }^{29}$ Chi mai vi fe' sì belle (no. 4); Oh quante volte, oh quante (no. 18); E qual legge m'imponi (no. 25).

${ }^{30}$ The collection comprises 857 items, catalogued in Bini, Il fondo Mario nella Biblioteca musicale di Santa Cecilia di Roma. I am very grateful to the author, Annalisi Bini, for personally ascertaining some details. 
the first genre. Although the Hamburg and Rome collections are not coextensive, there is a very substantial overlap of content, several "blocks" of adjacent cantatas appearing in exactly the same order in the two sources. ${ }^{31}$

The question we have immediately to ask is whether Barsanti copied from the scriptorium's repertory to form his own collection or the reverse, for both situations could in principle apply. Quite fortuitously, there is a tiny detail that proves Barsanti's priority. Alessandro Scarlatti composed at least eighteen cantatas (to ascertain the full number, one would need to study every poetic line in every piece!) that name as female protagonist a certain "Mitilde." Unusually, this name is not of Classical (Arcadian) origin but comes from medieval Germany (as "Mahthildis," "Mechtilde" and allied forms). ${ }^{32}$ Scarlatti himself always employs the standard Italian form as given. However, on two occasions out of a possible three, the Hamburg source changes the name to the form normal in Britain: "Matilda." 33 But in the copy of Da quel di che Mitilde (no. 84) acquired by Savage "Mitilde" does indeed transmute into "Matilda." Since Barsanti here took the opportunity to alter the previously accepted (or overlooked) "Mitilde" to "Matilda," we can be certain that he himself was the instigator of the change, the purpose behind which remains elusive. For its part, the Rome manuscript follows the Hamburg source in using the form "Matilda" for Amor, Mitilde è morta (no. 62). In this instance the hand is not Barsanti's, so the obvious inference to draw is that the Hamburg manuscript served his London colleagues as a prime source of cantatas to copy.

Since the Roman volumes contain no cantata entered after no. 78 in the Hamburg source, ${ }^{34}$ whereas Savage's manuscript goes up to no. $126,{ }^{35}$ their compilation probably predates the completion of the latter. 1733/1734, shortly after the initiation of the Opera of the Nobility, would be a possible time.

Barsanti's own contributions as a copyist to the Roman collection number only two so far discovered. One, predictably, is a cantata of his own composition: Chi mai vi fe' sì belle. ${ }^{36}$ The other, which fails to name the composer, is Marcello's Quella, Fileno, quella ch'un tempo. ${ }^{37}$

${ }^{31}$ In all, there are over 50 cantatas from the Hamburg manuscript - the number will once have been higher, if one reckons with losses over time - preserved in Rome among the identified volumes.

${ }^{32}$ It would be worth investigating whether "Mitilde" was used by Scarlatti, and perhaps others (a "Mitilde" cantata by Mancini is also known), as a cover name for a patroness or lady at court. This convention of using Arcadian pseudonyms is described in Talbot, Chamber Cantatas of Antonio Vivaldi, 99-102.

${ }^{33}$ Thus we have Amor, Matilda è morta (no. 62) and Il genio di Matilda mente non sia (no. 89), while Da quel dì che Mitilde (no. 84) escapes alteration.

${ }^{34}$ Sandoni's Pallida nel sembiante.

${ }_{35}$ Porpora's Questo è il platano frondoso.

${ }^{36}$ A. Ms. 3702, fols. 145r-148r. This autograph manuscript exhibits several small variants vis-à-vis the Hamburg text. The relationship needs further study, but preliminary analysis suggests that the Rome text is the earlier: the manuscript transmitting it was perhaps discarded by Barsanti precisely because it had been superseded by the "reference" copy in the Hamburg volume.

${ }^{37}$ A. Ms. 4771, fols. 11r-14v. The identification of the hand was made by Annalisa Bini. 


\section{Items 4-9}

The largest single copying task Barsanti is known to have undertaken for a customer is a six-volume set of selected Italian-language chamber duets (for two voices plus continuo) by several composers. These scores were owned, and probably also commissioned, by the blind organist and composer John Stanley (1712-1786). Shortly after Stanley's death his music was auctioned at Christie's on 24 June 1786, where the duets, listed as Lot 23, were described as "Duets by various masters, 6 v[olumes]." 38 Stanley's friend Sir John Hawkins purchased the volumes, which he then donated to the library of the British Museum (today, the British Library: GB-Lbl). The content of the volumes is as follows:

\begin{tabular}{|l|l|}
\hline Add. MS 5322 & 12 duets by Handel. ${ }^{*}$ \\
\hline Add. MS 5329 & 26 duets mostly for soprano and bass by Steffani. \\
\hline Add. MS 5330 & 30 duets for soprano and alto by Steffani. \\
\hline Add. MS 5331 & 20 duets mostly for soprano and tenor by Steffani. \\
\hline Add. MS 5332 & 21 duets for two sopranos by Steffani. \\
\hline Add. MS 5335 & $\begin{array}{l}\text { 19 duets, variously by Torri (8), Feroci (6), Stradella (2), Ercole Bernabei (1), Francesco } \\
\text { Maria Veracini (1) and Francesco Antonio Pistocchi (1). }\end{array}$ \\
\hline
\end{tabular}

This source is the one identified as "Y" in Konstanze Musketa's critical edition of Handel's chamber duets and terzets: Georg Friedrich Händel, Kammerduette, Kammerterzette, Hallische Händel-Ausgabe V/7 (Kassel: Bärenreiter, 2011), 202. Musketa dates the copy to after 1745 , which looks credible.

On this occasion Barsanti, surely wisely, refrained from adding anything of his own.

\section{Item 10}

The library of Birmingham University possesses a manuscript of twenty chamber duets for soprano and tenor by Steffani in Barsanti's hand..$^{39}$ Its content coincides almost entirely with that of GB-Lbl, Add. MS 5331. The title states that it was copied from the collection of Fredrick Louis, Prince of Wales (1707-1751), and a bookplate shows that it was owned by Lawrence (or Laurence) Dundas (1712-1781), one of Barsanti's most loyal Scottish patrons. Starting out as a wine merchant, Dundas became exceedingly wealthy through being a government contractor, parliamentarian (with a reputation for venality) and sugar plantation owner. He subscribed to Barsanti's Opp. 4 and 5, and the dedicatee of

${ }^{38}$ A Catalogue of all the Capital Musical Instruments, Extensive and Valuable Collection of Manuscript, and Other Music [...] Late the Property of John Stanley, Esq. M.B. dec[eased] (London: Christie, 1786), 3.

${ }^{39}$ Barber MS 5005, with a bibliographical description in Fenlon, Catalogue, 117-118. The folios number 108, and the recto side of fol. 1 has a title reading: "Duetti dell'Abate Vescovo Stefani | per Soprano e Tenore out of y:e | Collection of his Royall Highness Frederick Prince of Wales \&c \&c \&c." We learn from Hawkins, General History, 4:290n, that Frederick's collection of chamber duets by Steffani comprised several volumes (incompletely preserved as GB-Lbl, RM 23.k.13-20) inherited from his mother, Queen Caroline, for whom the copies had been made in Hanover. As Fenlon observes, the duets copied by Barsanti not present in the eight surviving volumes in the Royal Music Library could well have been taken from the several volumes known to have been lost. 
Op. 6 was his wife Margaret (1715-1802). The bookplate must have been affixed no earlier than 1762, since it proclaims Dundas's title of baronet, conferred in that year. However, bearing in mind that Frederick Louis's death acts as a terminus ad quem, Dundas probably received the volume at some point between 1743 (when Barsanti returned from Scotland) and 1751, adding the bookplate only later. Very likely, Dundas was the commissioner and first owner of the duets. It is interesting to know that Barsanti was granted access to a private royal collection, a privilege that must have enhanced his status as a copyist.

\section{Item 11}

The Bibliotheca Bodmeriana at Cologny-Genève, Switzerland (CH-CObodmer), possesses an album containing keyboard music (including transcriptions), songs suited to self-accompaniment at the keyboard and pieces for solo treble instrument and continuo. ${ }^{40}$ Ignoring items of uncertain authorship, at least nine composers are represented: Handel, Rameau, Barsanti, Hasse, Chelleri, Telemann, Geminiani, Nicolas Renier and Lewis Granom. At least six scribes, apparently working in considerable haste, collaborated to compile the album. Two of them, Handel and Barsanti, combined copying with composition (or re-composition of earlier music). Barsanti's specific contribution falls into two distinct categories. The first consists of a group of six keyboard pieces by Rameau (though not naming him) taken from his second and third harpsichord books. ${ }^{41}$ There are mostly straightforward copies, although Barsanti simplifies the ornamentation a little and is not above making some almost unnoticeable would-be compositional improvements. ${ }^{42}$ The second contribution is a pretty set of six French airs tendres for voice and continuo. ${ }^{43}$ The originals, from which Barsanti took the strophic text and melody (which he modified considerably to suit his more Italianate taste), were all monophonic airs à voix seule, so the basses, recalling those of his Old Scots Tunes of 1742, must be entirely his handiwork, as copious compositional corrections suggest. He omits to write his name anywhere, and one wonders whether Handel or any of the other scribes (none of whom has been identified) was aware of his compositional interventions.

The date of the album's compilation and the person and occasion for which it was intended are the subject of close investigation in the cited article. Circumstantial evidence strongly suggests that it was put together in London shortly after Barsanti's return from Scotland in mid-1743 and that its likely recipient was the highly musical and linguistically gifted Princess Louisa (1724-1751), who left London permanently in October 1743 to marry the crown prince of Denmark.

${ }^{40}$ Ms. 11641-7. On this complex and in many respects mysterious album, see Talbot, "Leaving Present for Princess Louisa?"

${ }^{41}$ On pp. 73-79 and 90-97. The two collections in question are the Pièces de clavessin of 1724 and the Nouvelles Suites de pièces de clavecin of 1729/1730.

${ }^{42}$ For example, in bar 5 of the G Major Menuet from the Nouvelles Suites, where Barsanti substitutes major chords of C and G for Rameau's minor chords of A and $\mathrm{E}$. The passage is shown in facsimile in Cameron and Talbot, "Many-Sided Musician," 132.

${ }^{43}$ The six airs, entered on pp. 80-89, are: La jeune Iris dans un boccage; Maman, ne grondés pas; Ce n'est plus un mistère; Je n'entends plus dessous l'ormeau; Il faut qu'on aime une fois; Un jour dans un verd boccage. 


\section{Item 12}

This is a calligraphic manuscript entirely in Barsanti's hand containing thirteen mostly five-part madrigals in score. The first eight are by Italian masters of the seventeenth and eighteenth centuries (Antonio Cifra, Agostino Steffani, Alessandro Stradella, Antonio Lotti), the last five by English composers (Michael East, Ellis Gibbons, John Bennet, John Hilton, Thomas Morley) and taken from The Triumphs of Oriana (1601). The manuscript is held by the Royal Music Library deposited at the British Library. ${ }^{44}$ Among other possibilities, it could have been copied especially for the royal music collection.

\section{Item 13}

The manuscript RM 22.m.2 in the Royal Music Library is a collection of twelve sacred vocal compositions by Palestrina in score: nine pieces taken from his Offertoria of 1593; two from his fifth book of motets (1584); and a singleton, the invitatory from the Office for the Dead Regem cum omnia vivunt; the last work is generally accepted as authentic, although a Berlin source attributes it to Johann Joseph Fux. ${ }^{45}$ Consisting of 29 folios, the manuscript was written out by two scribes: fols. 1-5, containing the first three pieces and part of the fourth (Ave Maria), are in one hand - obviously English and, to judge from the sham-antique notational style, belonging to someone firmly in the "ancient music" camp - while fols. 6-29 are in Barsanti's hand. The collection appears to be copied from another manuscript in the same collection, RM 24.c.10 (1.), with the exception of the ninth piece, Regem cum omnia vivunt (on fols. 20v-21r), which has evidently been inserted, perhaps surreptitiously, by Barsanti himself. The motive behind the addition may have been simple admiration for the music of this invitatory, which is a double canon. The original destination of this manuscript, if other than the royal collection itself, is unclear.

\section{Items 14.1 and 14.2}

RM 24.d.15 (1-4) is a binder's collection assembled in the nineteenth century, although its first two component parts, and possibly all four, clearly share a provenance. The first section (fols. $1 \mathrm{r}-13 \mathrm{v}$ ) begins with ten four-part motets by Victoria copied by a hand similar to, but not identical with, the one that opened item 13. This hand is identifiable with some confidence as that of John Keeble (ca. 1711-1786), a prominent London organist, music theorist and collector of music, who, as a former pupil of Johann Christoph Pepusch upholding the latter's tradition, had the same general musical orientation as Barsanti. ${ }^{46}$ Taking over from Keeble lower down on fol. 13v and continuing to the end of the section on fol. 43v, Barsanti added eleven motets by Palestrina taken from the Motecta festorum of 1590 and the second book of motets for four voices of 1604 .

${ }^{44}$ RM 24.c.16 (1-13).

${ }^{45}$ Berlin, Deutsche Staatsbibliothek P. K. (D-B), Am.B 415. Köchel's Fux catalogue of 1872 accepted this attribution.

${ }^{46}$ The identification was made after comparison with (a) the musical and textual handwriting of a collection of madrigali spirituali by Palestrina (GB-Lbl, Add. MS 31408) that belonged to Keeble and contains the autograph inscription (of ownership) "J. Keeble" and (b) the handwriting of invoices by Keeble (for music copying and other services) reproduced in facsimile in Goodwill, Musical Involvement of the Landed Classes in Eastern Scotland, 43-44. 
The second section, occupying three folios, is a single composition in Barsanti's hand: a four-part responsory, Quem dicunt homines, headed "Adrianus Prenestini's Master." ${ }^{37}$ "Adrianus" is presumably either Adriaan Willaert or Adrianus "Petit" Coclico, while "Prenestini" is a synonym for "Palestrina." In reality, however, this motet is by neither Willaert nor Coclico but by Jean Richafort: the association with Palestrina may have been suggested by the fact that this composer was among several who wrote parody masses on Richafort's composition. ${ }^{48}$

In the supernumerary works inserted into items 13 and 14 we catch a whiff of Barsanti's missionary zeal - but this time on behalf of favourite works by other composers, not his own compositions.

\section{Item 15}

In 1883 the newly founded Royal College of Music in London (GB-Lcm) purchased via public subscription the large library of the Sacred Harmonic Society. Among the items acquired was a manuscript, entirely in Barsanti's hand, containing the scores of Gesualdo's first two books of five-part madrigals. ${ }^{49}$ On the vacant verso side of the final folio (fol. 77), Barsanti left a space-filler amounting almost to a calling card: a five-bar, four-part catch of his own composition set to words from the Book of Proverbs opening "Happy is the man that findeth wisdom" (see Fig. 1). He must have been confident of its favourable reception, for he acknowledged authorship of it in the heading: "Barsanti's catch for four parts." There is something incongruous, perhaps deliberately ironic, in this startling juxtaposition of the hedonistic and the moralistic, the chromatic and the diatonic, the convoluted and the transparent. However, congruence exists at a more basic level: that of devotion to the polyphony of the past. Nothing further is known about the provenance of this manuscript.

\section{Item 16}

Another manuscript entirely in Barsanti's hand at the Royal College of Music is one containing Pergolesi's Stabat Mater, followed by a transposed version in A Minor of his Salve Regina in C Minor. ${ }^{50}$ Since the Sacred Harmonic Society acquired the manuscript in 1849 from Vincent Novello, to whom it had been left by the eminent double-bass player and collector Domenico Dragonetti, active in Britain from 1794 onwards, there is a possibility that it is a stray item from the library of the AAM. As H. Diack Johnstone has noted, both works were included in the 1761 edition of The Words of Such Pieces as are Most Usually Performed by the Academy of Ancient Music. ${ }^{51}$ Andrew Woolley has reported the presence of the initials "M. T." in gilt tooling on the volume's cover. ${ }^{52}$ While

${ }^{47}$ It seems unlikely that this copy was originally a free-standing manuscript as its separate shelfmark implies.

${ }^{48}$ The third section of the same volume transmits an Adjutorium nostrum in an unidentified third hand, while the fourth section consists of Thomas Morley's De profundis in a copy by Henry Needler.

${ }^{49}$ MS 208.

${ }^{50}$ MS 483. The Stabat Mater occupies pp. 1-48, the Salve Regina pp. 49-61.

51 Johnstone, "Westminster Abbey and the Academy of Ancient Music," 355.

52 Woolley, "Neapolitan Sacred Music in Eighteenth-Century Britain," 191. I am grateful to the 


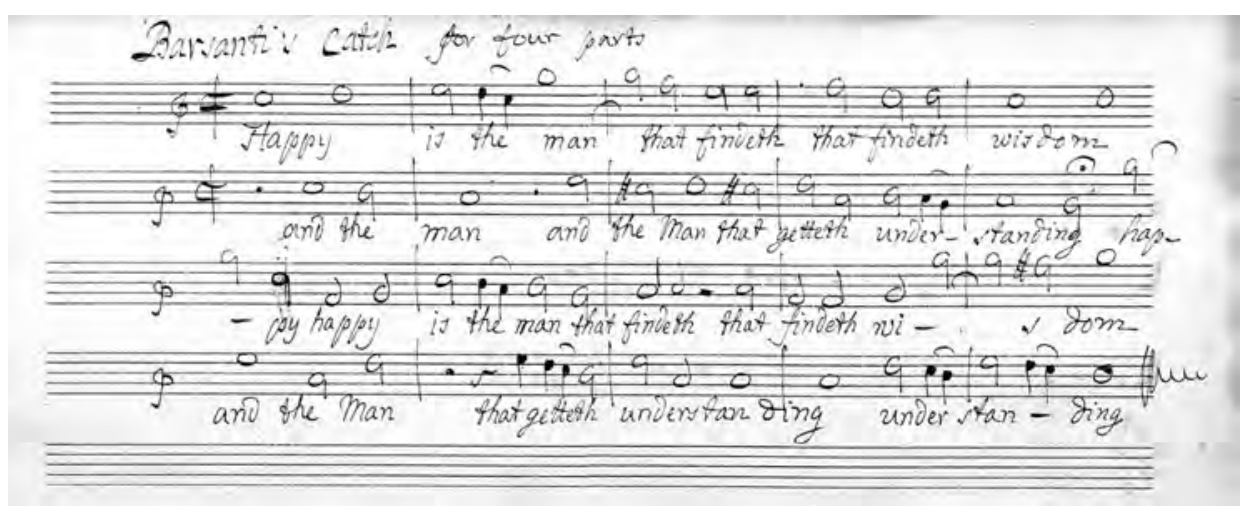

Figure 1 Barsanti's catch Happy is the man that findeth wisdom (London, Royal College of Music, MS 208, fol. 77v; reproduced with kind permission).

one should not jump to conclusions, there is a possibility worth exploring further that the initials are those of Moses Toghill (1744-1825), a cleric also esteemed as a singer (in both bass and countertenor registers) and cellist. ${ }^{53}$

These two Pergolesi works are the first examples so far discussed of the more mainstream area of Italian musical repertory with which Barsanti could sometimes become involved as a copyist, this composer being admired equally by partisans of the ancient and the modern.

\section{Item 17}

MS 1029 at the Royal College of Music is a complete set of parts for the motet Luminosa consurgit by Domingo (Domenico) Terradellas (1711-1751), three instrumental parts being in the hand of an unknown scribe, probably Italian, and three vocal parts in Barsanti's. ${ }^{54}$ The same unidentified copyist wrote out the matching full score, which is the manuscript CG 56 in the library of Westminster Abbey, London (GB-Lwa). Because of the certainty that the score once belonged to the AAM, we here have clear evidence of Barsanti's connection, at least in a "service" role, to the Academy. Johnstone provides

author for giving me sight of this article prior to publication.

${ }^{53}$ Born in Pucklechurch, Gloucestershire, Toghill came to notice as a boy chorister at New College, Oxford. He made a successful career in the Anglican church, initially as a "vicar choral" but ending his days as Canon Residentiary and Precentor of Chichester Cathedral. He is not recorded as a collector of music, although in 1780 he was a subscriber to John Beckwith's Six Voluntaries for the Organ, Harpsichord etc. Ending his life as a wealthy man, Toghill would have had the means to possess such a handsomely bound volume.

${ }^{54}$ See Johnstone, "Westminster Abbey and the Academy of Ancient Music," 356-357; and Woolley, "Neapolitan Sacred Music in Eighteenth-Century Britain," 190-191. GB-Lcm, MS 1029, also includes some parts of no direct relevance added for a later performance. Terradellas was familiar to London audiences through his visit of 1746-1747. 
the information that the paper used for the score is datable, via Handel's use of it, to 1748-1751; a similar date doubtless applies to the parts. ${ }^{55}$

\section{Item 18}

Ms 1074 in the same collection, earlier owned by the Sacred Harmonic Society, is a binder's collection of scores containing thirteen sacred vocal compositions by diverse composers, among whom Francesco Gasparini, Gaetano Carpani (his surname mis-spelled as "Carpari") and Edward Lupi are named. Two anonymous multi-sectional motets written out by Barsanti and occupying, respectively, pp. 102-110 and pp. 111-125 are clearly his compositions, as not only their style but also a few compositional corrections show. The first, Christus factus est, is scored for SATB (but for correct harmony needs continuo support for the bass at the sub-octave). The second, Laudate Dominum omnes gentes, described as "Int[roit]us" in an annotation inserted before the first system, is for two three-part choirs (respectively, SAB and SAT) with independent continuo support. This is certainly the kind of music that both the AAM and the Madrigal Society performed recreationally, if not necessarily before the public, although the source provides no precise clues to context.

\section{Item 19}

Barsanti copied a further sacred vocal work by (or at any rate attributed to) Pergolesi: one of two C Minor settings of the Miserere (Paymer 71). This is scored for SATB soloists, SATB choir, strings and continuo. ${ }^{56}$ The score is massive, containing fifteen movements and running to 84 folios in oblong quarto format. Since this manuscript, the only eighteenth-century source for the work surviving in Britain, is preserved among the volumes in the library of Westminster Abbey identified as belonging earlier to the AAM, that body was probably its first destination and the commissioner of the copy. ${ }^{57}$ An interesting detail: in the first movement, Barsanti subsequently inked in numerous minor alterations (evidently intended as compositional improvements and written in small-sized notes and underlaid text). This act not only typifies his "interventionist" leanings as a copyist, but suggests, moreover, that he was personally involved in the practical aspects of this work's performance.

\section{Items 20.1 and 20.2}

Another major work of copying undertaken by Barsanti in his later years for the AAM, as it appears, was an anthology containing 61 four-part polyphonic vocal compositions. The score is preserved in the library of Westminster Abbey, ${ }^{58}$ but the four matching partbooks (likewise entirely in Barsanti's hand), which at one time belonged to the

55 Johnstone, "Westminster Abbey and the Academy of Ancient Music," 356.

${ }^{56}$ Both settings are listed as spurious in the second edition of the New Grove (2001). The exclusion of Paymer 71 from the Pergolesian canon seems to have more to do with the absence of positive indices than the presence of negative ones. There are no contrary attributions in the source tradition. The music appears a perfect exemplar of Neapolitan style in the period 1730-1750.

${ }^{57}$ CG 26. See Johnstone, "Westminster Abbey and the Academy of Ancient Music," 355.

${ }^{58}$ CG 59. 
counter-tenor James Horsfall, a member of the Westminster Abbey choir, participant in AAM concerts in 1787-1788 and member of the Madrigal Society from 1791 onwards, passed via the collector Julian Marshall to the British Library in $1881 . .^{59}$

The collection opens with seventeen English-language madrigals by John Bennet, representing the complete content of his Madrigalls for Four Voyces of 1599. However, Barsanti's copy text was not the published edition but one or more manuscript sources of these pieces preserved in the archives of the Madrigal Society, with which they share several modifications to the underlaid texts. As a member of the Madrigal Society from 1759, Barsanti had ready access to its library, and since relations between the former and the AAM were very cordial (AAM members had the right to be admitted to Madrigal Society meetings gratis), there would have been no obstacle to co-operation of this kind..$^{60}$ Curiously, Bennet's name is not disclosed in the scores, although it appears in the partbooks for two of the madrigals.

The bulk of the collection (nos. 18-55, the number 45 being accidentally used for two pieces) comprises 38 Italian-language madrigals. The method of anthologizing is typical of Barsanti, resembling that used for the cantata manuscript in Savage's possession (item 2). Sometimes, he enters works in blocks as found in the copy text; sometimes he darts from one source to another. The result is a good cross-section of the international repertory of four-part Italian madrigals. Palestrina is represented by five madrigals and the obscure Piedmontese composer Antonio Dueto even by six, but the eighteen others all have between one and three. With one exception (a Dueto madrigal, no. 30), the composers' names are given in the score but omitted from the parts.

Barsanti closes the collection with five sacred pieces. Nos. 58-60 are motets in which Palestrina is named as the composer, although Victoria is the actual author of the last (Magi viderunt stellam). Nos. 56 and 57 are pieces by Barsanti, who in the score (the partbooks have no heading other than the serial numbers) prefaces his "FMB" monogram to each. No. 57, a multi-sectional Latin motet ( $O$ salutaris hostia) resembling the Christus factus est discussed earlier, carries a date: $1736 .{ }^{61}$ This is clearly a date of composition, not of copying, and suggests how far the composer's interest in the stile antico went back. No. 56 is truly extraordinary, a piece sui generis. It is a polyphonic setting of the first six verses of the Hebrew text of Psalm 74/75 (counting the preface as verse 1) employing the orally transmitted melody of a traditional Sabbath chant sung by the Sephardic (Spanishand Portuguese-Jewish) community of Amsterdam. Barsanti uses a homespun, slightly garbled system of transliteration from Hebrew characters which follows the phonetics sometimes of English, sometimes of Italian. The opening verse is rendered as "Lamna seah al taschet mizmor-le a saphsir." ${ }^{2}$ The chant is published in an arrangement for melody and

${ }^{59}$ Add. MS 31440.

${ }^{60}$ See Thomas Oliphant, Brief Account of the Madrigal Society, 7.

${ }^{61}$ The opening of $O$ salutaris hostia, showing the date and monogram, is reproduced as a plate in Johnstone, "Westminster Abbey and the Academy of Ancient Music," 354.

${ }^{62}$ A more modern and systematic Romanized version would be: "Lammenatztzeach 'al-tashchet mizmor le-Asaf shir." I am grateful to Don Harrán for advice on the meaning and transliteration of the Hebrew and for alerting me to the source cited in the next footnote. 
vocal (or piano) accompaniment in a nineteenth-century collection of Sephardic sacred songs. ${ }^{63}$ Barsanti adheres remarkably closely to the original melody, treated it with great originality in a series of six strophic variations, the three accompanying voices weaving madrigalian counterpoints against, and occasionally imitating, the melody in the soprano voice. In this strange but moving piece his interests in "ancient" and "national" music achieve perfect fusion.

\section{Item 21}

In 1760 or slightly earlier Barsanti published privately in score his Sei antifone, op. 5. These are five-part (in one case, six-part) Latin motets for recreational and concert use ${ }^{64}$ Their pioneering, albeit rather idiosyncratic, adoption of the stile antico attracted approving notice. ${ }^{65}$ Among the 82 subscribers were the AAM and the Madrigal Society, whose copies survive today. ${ }^{66}$

The library of Westminster Abbey possesses a manuscript score of the third motet, Agios o Theos, and nineteen miscellaneous manuscript parts for the second (Asperges $m e$ ), third and fourth (De profundis) motets. ${ }^{67}$ The score is not in Barsanti's hand and transmits a version of the motet differing at many points from the published score, of which it appears to be a primitive version. At certain points, a second hand, which looks like that of Barsanti himself, has made emendations, and these match in part the text of the definitive version. The inference to be drawn is that Barsanti had the piece tried out at the AAM prior to publication. All the parts are in Barsanti's hand. The ten for Agios $O$ Theos comprise: (a) a full set of five vocal parts corresponding to the published text; (b) duplicate parts for tenor and bass; (c) three instrumental contrabass parts, of which one doubles the vocal bass, one slightly elaborates the line of the vocal bass, and one, provided with bass figures, acts as a basso seguente that on occasion follows the overlapping tenor, instead of the bass, line. These three versions appear to represent distinct chronological stages in the evolution of this added part, which is not present in the published score. The fourth motet, De profundis, has a full set of vocal parts (with duplicated tenor) plus a doubling contrabass part. The parts for the second motet, Asperges me, are only two: these are contrabass parts in duplicate with small deviations from the vocal bass, exactly as in the second of the contrabass parts for Agios o Theos.

Throughout these copies, even more than in the published Op. 5, Barsanti makes full use of a curious notational convention particularly prevalent among British adherents of the "ancient music" cult. This is to notate the music, Renaissance-style, as if without barlines and only then to superimpose the barlines. The result is the bisection of many breves and semibreves by a barline and the positioning of many barlines between note-heads and the

${ }^{63}$ Emanuel Aguilar, Ancient Melodies of the Liturgy of the Spanish and Portuguese Jews, 18 (of the music section).

${ }^{64}$ The third motet, Agios $o$ Theos, alternates Greek and Latin in accordance with liturgical usage.

${ }^{65}$ Kollmann, Essay on Practical Musical Composition, 30.

${ }^{66}$ GB-Lwa, CG 69, and GB-Lms, Mad. Soc. 13. (11.), respectively.

${ }^{67}$ The score is shelfmarked CG $1 \mathrm{a}$, the parts CG $1 \mathrm{~b}$. 
following dots of addition. ${ }^{68}$ Consequently, the need for ties is almost eliminated. This is one sign among many of Barsanti's willing adjustment to the British environment.

The importance of these parts is that they constitute the only surviving performance material specially prepared by the composer for his own music. The afterthoughts they contain reinforce the general impression that Barsanti regarded all works, including his own, as "works in progress" apt for further revision.

\section{Barsanti: A Man of Many Parts}

Although the twenty-one items discussed provide a remarkably wide range of content and context for Barsanti's activity as a copyist, they fall far short of the full story. To point out just two obvious lacunae: there is nothing dating from Barsanti's eight years in Scotland (1735-1743), although we know that the Edinburgh Musical Society included "writing" (i.e., copying) music as one of his duties, and the surviving copies in his hand include no instrumental ensemble music, although this domain dominated his publications and work as a teacher and concert promoter.

The importance of music copying to Barsanti's career has several distinct aspects. First, it helped to secure his livelihood. Once established as a copyist - moreover, one with the advantage of native-speaker expertise in the sphere of Italian vocal music - he could count on gaining a modest but at least guaranteed income from it in the intervals between more satisfying or profitable work. Second, it fulfilled an educative, instructional role. Music copying was seen in earlier centuries as an opportunity for a musician to pick up, via immersion and careful observation, the compositional principles practised by the "best masters." This function was especially important as a point of entry into a less familiar musical style such as Renaissance polyphony. Third, it was a highly social practice. Music copying forged personal in addition to contractual links: between one musician and another; between master and pupil; or between musician and patron or customer. For a musician such as Barsanti with a relatively low public visibility, it provided a simple means of retaining and expanding contacts. Finally, the relative autonomy often enjoyed by a music copyist allowed him in suitable circumstances to inject a personal agenda. It enabled Barsanti to revise - normally silently - the text copied, and it sometimes allowed him, openly or furtively, to append or intercalate pieces of his own composition that might be difficult to place in circulation by other means.

Reinhard Strohm once ended an essay on Vivaldi's career in opera by describing his subject memorably as "the best composer among the impresarios - the best impresario among the composers." ${ }^{69}$ One is tempted to adapt this formula for Barsanti and call him "the best composer among the copyists - the best copyist among the composers." Certainly,

${ }^{68}$ Doubtless, this custom first arose when barlines were manually added in the seventeenth century and subsequently to printed or manuscript music that previously lacked them: what was originally a makeshift solution then matured into an established notational practice.

${ }^{69}$ Strohm, Essays on Handel and Italian Opera, 163. 
within eighteenth-century Britain his combination of the two skills was uncommonly fruitful for both of them.

\section{Bibliography}

Aguilar, Emanuel. The Ancient Melodies of the Liturgy of the Spanish and Portuguese Jews Preceded by an Historical Essay of the Poets, Poetry and Melodies of the Sephardic Liturgy by the Rev. D. A. De Sola. London: Wessel, 1857.

[Baretti, Giuseppe]. The Voice of Discord, or the Battle of the Fiddles: A History of a Seditious and Unnatural Attempt on the Lives and Properties of Fifty Singers and Fiddlers. London: Owen and Snelling, 1753.

Beeks, Graydon. "Making a Living in the Pit: The Career of Thomas Rawlings." HändelJahrbuch 49 (2003): 223-238.

Bini, Annalisa. Il fondo Mario nella Biblioteca musicale di Santa Cecilia di Roma: catalogo di manoscritti. Rome: Edizioni Torre d'Orfeo, 1995.

Burney, Charles. The Present State of Music in France and Italy, or, The Journal of a Tour through Those Countries, Undertaken to Collect Materials for a General History of Music. London: Becket, 1771.

Burrows, Donald, and Martha J. Ronish. A Catalogue of Handel's Musical Autographs. Oxford: Clarendon Press, 1994.

Cameron, Jasmin, and Michael Talbot. "A Many-Sided Musician: The Life of Francesco Barsanti (c. 1690-1775) Revisited.” Recercare 25, nos. 1-2 (2013): 95-154.

Fenlon, Iain. Catalogue of the Music and Musical Manuscripts before 1801 in the Music Library of the University of Birmingham Barber Institute of Fine Arts. London: Mansell, 1976.

Goodwill, Helen. The Musical Involvement of the Landed Classes in Eastern Scotland, 1685-1760. PhD diss., University of Edinburgh, 2000.

Halton, Rosalind, and Michael Talbot. "'Choice Things of Value': The Mysterious Genesis and Character of the VI Concertos in Seven Parts Attributed to Alessandro Scarlatti." Eighteenth-Century Music 12 (2014): 9-33.

Hawkins, Sir John. A General History of the Science and Practice of Music, 5 vols. London: Payne, 1776.

Hawkins, Matilda-Laetitia. Anecdotes, Biographical Sketches and Memoirs, 3 vols. London: Rivington, 1822-1824.

Johnstone, H. Diack. "Westminster Abbey and the Academy of Ancient Music: A Library Once Lost and Now Partially Recovered.” Music \& Letters 95 (2014): 329-373.

Kollmann, Augustus Frederic Christopher. Essay on Practical Musical Composition According to the Nature of that Science and the Principles of the Greatest Musical Authors. London: author, 1799.

Landgraf, Annette, and David Vickers, ed. The Cambridge Handel Encyclopedia. Cambridge: Cambridge University Press, 2009. 
Marpurg, Friedrich Wilhelm. Untitled article (dated 25.10.1749). Der critische Musicus an der Spree 1 (1750): 311-315.

Oliphant, Thomas. A Brief Account of the Madrigal Society from its Institution in 1741, up to the Present Period. London: Calkin and Budd, 1835.

Rosselli, John. The Opera Industry in Italy from Cimarosa to Verdi: The Role of the Impresario. Cambridge: Cambridge University Press, 1984.

Strohm, Reinhard. Essays on Handel and Italian Opera. Cambridge: Cambridge University Press, 1985.

Talbot, Michael. "A Leaving Present for Princess Louisa? Handel, Barsanti and Bodmer Ms. 11461-7.” Händel-Jahrbuch 61 (2015): 343-383.

___ "An Unexpected Handel Copyist: Francesco Barsanti." The Handel Institute Newsletter 24, no. 2 (2013): 1-3.

____ "Francesco Barsanti and the Lure of National Song." Studi musicali (forthcoming).

_- The Chamber Cantatas of Antonio Vivaldi. Woodbridge: The Boydell Press, 2006.

White, Micky, and Michael Talbot. "Pietro Mauro, detto 'il Vivaldi': Failed Tenor, Failed Impresario, Failed Husband, Acclaimed Copyist." In Vivaldi, "Motezuma" and the Opera Seria: Essays on a Newly Discovered Work and Its Background, edited by Michael Talbot, 37-61. Speculum Musicum 13. Turnhout: Brepols, 2008.

Woolley, Andrew. "Neapolitan Sacred Music in Eighteenth-Century Britain: The Case of Pergolesi's Messa di S. Emidio.” Studi pergolesiani/Pergolesi Studies 10 (2015): 186-207. 


\section{MARLJIVI PREPISOVALEC IN SKROMNI SKLADATELJ \\ DVA OBRAZA FRANCESCA BARSANTIJA (OK. 1690-1775)}

\section{Povzetek}

Francesca Barsantija glasbeniki in muzikologi poznajo predvsem kot pomembnega člana italijanske skupnosti osrednjih desetletij 18. stoletja v Britaniji, še posebno skladatelja privlačnih in izvirnih sonat za kljunasto in prečno flavto, godalnih koncertov z dodatnimi pihali in timpani, uverturah za godala in trio sonatah. Manj znana je njegova sicer še zanimivejša vokalna glasba (moteti, kantate, kanoni, šansone in en madrigal), ki se povečini navezuje na njegovo aktivno gojenje in posnemanje »starih« kot tudi »nacionalnih« glasbenih zvrsti. Barsanti je za širjenje teh skladb uporabil nenavadno pot. Tako kot veliko preprostih orkestrskih glasbenikov svojega časa, ki jim ni bilo dano, da bi nastopali kot solisti (ali pa si niso upali), je za svoj dodatni prihodek prepisoval glasbo. Ohranjenih je več kot dvajset rokopisov, ki so v celoti ali deloma delo njegove roke. Približno tretjina le-teh vsebuje tudi njegova lastna vokalna dela, ki jih je zvito dodal ter pri tem pogosto opustil navedbo skladateljevega imena.

Barsantijev zapis glasbe je zelo značilen. Njegova prepoznava je izhajala iz primerjave podpisanega besedila $\mathrm{z}$ dokumenti, ki so nedvomno avtografi (pisma in en račun), a tudi v smislu manjših skladateljskih popravkov v nekaterih rokopisih, kjer se je podpisal s svojim imenom. Dejstvo, da so rokopisi glasbe, ki jih pripisujemo Barsantiju, brez izjeme vsi napisani z isto roko, le še dodatno potrjuje zgornjo domnevo.

Po splošni predstavitvi vloge glasbenih kopistov pri razširjanju glasbe, še posebno v Angliji, se prispevek osredotoča na analizo posameznih enot vsega Barsantijevega znanega prepisovalskega opusa. Posebne pozornosti bo deležen aspekt namena in končnega cilja njegovih prepisov, sodelovanja $\mathrm{z}$ drugimi kopisti in skladbam (predvsem Barsantijeva vokalna dela, a tudi skladbe nekaterih drugih avtorjev), ki so bile očitno na njegovo pobudo vstavljene ali dodane na koncu, da bi se tako razširile oziroma preprosto ohranile. Te dodane skladbe so tako kratke kot tudi zelo dolge in nekatere so prav posebne - zlasti je zanimiva madrigalna uglasbitev hebrejskega besedila, kjer je uporabljena sefardska duhovna melodija, na katero je verjetno naletel v času svojega drugega obiska v Amsterdamu. Po zaslugi te diskretne samo-promocije, ki ji naročniki rokopisov očitno niso nasprotovali, imamo danes solidno zbirko Barsantijeve vokalne glasbe. Njegov primer razkriva tudi način, kako je lahko prepisovalec, ki je bil hkrati tudi skladatelj, združil svoje »mehansko« in »ustvarjalno« delo. 